\title{
A CRITIQUE OF THE NATIONAL LABOR RELATIONS BOARD'S PERFORMANCE IN POLICY FORMULATION: ADJUDICATION AND RULE-MAKING *
}

\section{CoRNELITUS J. PECK $\dagger$}

In the spring of 1968, the recent performance of the National Labor Relations Board was subjected to scrutiny and criticism in hearings before a Subcommittee of the Senate Judiciary Committee. ${ }^{2}$ The announcement of the Subcommittee's hearings gave special emphasis to problems associated with the combination of legislative, executive, and judicial powers in administrative agencies. Concern was expressed over the threat to the Constitution and representative government if administrators assumed powers to modify or ignore the will of Congress expressed in statutes. It was explained that the National Labor Relations Board was selected as the first agency for examination because of the importance of the functions which it performs and because of specific criticism that the Board had usurped congressional functions by applying its own views of desirable labor policy rather than the policies that Congress had established by statute. ${ }^{2}$ In large part the witnesses before the Subcommittee attempted to document undesirable and unauthorized announcements and changes of policy made by the Board in recent years.

There can be no doubt that numerous and significant changes of policy have followed changes in Board membership resulting from appointments by Presidents of different political parties. The changes have taken place without modification of the statutory language, and must therefore be attributed to different views of the administrators either as to what would be sound labor policy or, at best, as to what labor policy Congress meant to establish.

A good example is the altered construction of section $8(\mathrm{~b})(1)(\mathrm{A})^{3}$

* This article, substantially in its present form, was first presented as a statement before the Subcommittee on Separation of Powers, Senate Judiciary Committee, April 1, 1968.

$\dagger$ Professor of Law, University of Washington. B.S. 1944, LL.B. 1949, Harvard University. Member, Massachusetts and Washington Bars.

1 Hearings on Congressional Oversight of Independent Administrative Agencies Before the Subcomm. on Separation of Powers of the Senate Comm. on the Judiciary, 90th Cong., 2d Sess. (1968) [hereinafter cited as 1968 Hearings].

21968 Hearings -

3 National Labor Relations Act [hereinafter cited as NLRA] §8(b)(1)(A), 29 U.S.C. \$158(b) (1) (A) (1964). 
by Eisenhowever appointees three years after they constituted a majority on the Board and ten years after enactment of the TaftHartley Act. At that date they reached the conclusion-later rejected by the Supreme Court-that the section prohibited recognitional or organizational picketing. ${ }^{4}$ One of the Board members later unguardedly described the action as based upon the following considerations :

(1) If it [recognitional and organizational picketing] wasn't against the law it ought to be, and (2) If the Supreme Court of the United States overruled us, it would at least bring to the attention of Congress a loophole in the law which it might remedy. ${ }^{5}$

The Eisenhower appointees attempted a comparable change in the same year when they held that exclusive hiring hall agreements were inherently discriminatory and violated the Act unless certain limitations upon the union's power were made in the collective bargaining agreement and published to prospective employees. ${ }^{6}$ The Supreme Court likewise disapproved of this attempted change, and a majority of the Court reminded the Board that where Congress "aimed its sanctions only at specific discriminatory practices, the Board can not go farther and establish a broader, more pervasive regulatory scheme." 7 The creativity of President Eisenhower's appointees can be found in other of their holdings: the decision that craft employees should not be denied craft representation because they are employed in highly integrated industries; ${ }^{8}$ the decision requiring a choice between participation in a representation election and prosecution of an $8(a)(5)^{9}$ unfair labor practice charge; ${ }^{10}$ the decisions outlawing "hot cargo" clauses ${ }^{11}$ and the 1954 change raising the NLRB's jurisdictional

4 Teamsters Local 639, 119 N.L.R.B. 232 (1957), set aside, 274 F.2d 551 (D.C. Cir. 1958), aff'd, 362 U.S. 274 (1960).

5 Hearings before the Subcomm. on the National Labor Relations Board of the House Comm. on Education and Labor, 87th Cong., 1st Sess., pt. 2, at 1019 (1961). Board member Joseph A. Jenkins (not to be confused with incumbent member Howard Jenkins) explained that the quotation was taken from a speech delivered extemporaneously, and that he had later explained in answer to a question that he meant that when there were two equally valid competing legal theories, he would decide in favor of the one that appealed to his sense of justice. I $I$.

6 Associated General Contractors, Inc., 119 N.L.R.B. 883 (1957), enforcement denied, 270 F.2d 425 (9th Cir. 1959).

7 Teamsters Local 357 v. NLRB, 365 U.S. 667, 676 (1961).

8 American Potash \& Chem. Corp., 107 N.L.R.B. 1418 (1954).

8 NLRA § 8(a) (5), 29 U.S.C. \$ 158(a) (5) (1964).

10 Aiello Dairy Farms, 110 N.L.R.B. 1365 (1954).

11 Carpenters Local 1976, 113 N.L.R.B. 1210 (1955), enforced, 241 F.2d 147 (9th Cir. 1957), aff'd, 357 U.S. 93 (1958) ; Teamsters Local 554, 110 N.L.R.B. 1769 (1954). 
standards, ${ }^{12}$ apparently made without realization that the preemption doctrine would preclude employers from relying on and resorting to the generally employer-oriented principles of state law in labor disputes.

Soon after President Kennedy's appointees became a majority, it became obvious that changes in the law developed by the NLRB were directly and immediately traceable to changes in Board membership. The shape that prohibitions against recognitional and organizational picketing under section $8(\mathrm{~b})(7)^{13}$ had been taking under the direction of a Board controlled by Eisenhower appointees was quickly and drastically changed. ${ }^{14}$ A sense of the urgency with which the revision was made can be gained by observing that in one of the decisions in the series, an important change of policy, totally irrelevant to the case being decided, was announced in a footnote. ${ }^{15}$ Equally important changes were made by freeing from regulation activities previously thought to fall under the prohibitions against secondary picketing. ${ }^{16}$ No time was lost in reversing the Eisenhower appointees' ruling that an employer's decision to subcontract did not violate its duty to bargain, ${ }^{17}$ and limitations upon management's right to deliver speeches to massed audiences of employees on company time soon appeared. ${ }^{18}$ Conditions established for questioning employees about union activities or affiliation ${ }^{18}$ soon effectively overturned the Eisenhower appointees' earlier decision that such questioning did not per se constitute illegal interrogation. ${ }^{20}$ Indeed, so rapid was the change that one of the labor law reporting services found it appropriate to make a new index entry entitled "Prior decisions overruled by Board." 21 More recent decisions on establishing a union's bargaining status

12 NLRB Press Release R-445, 449, 34 L.R.R.M. 75 (July 15, 1954). See Breeding Transfer Co., 110 N.L.R.B. 493 (1954).

13 NLRA § 8(b) (7), 29 U.S.C. §158(b) (7) (1964).

14 Bachman Furniture Co., 134 N.L.R.B. 670 (1961) ; Blinne Constr. Co., 135 N.L.R.B. 1153 (1962); Crown Cafeteria, 135 N.L.R.B. 1183 (1962); Barker Bros. Corp., 138 N.L.R.B. 478 (1962).

15 In footnote 24 of the majority decision in Blinne Constr. Co., 135 N.L.R.B. 1153, 1166 (1962), it was announced that a union would not violate $\$ 8(\mathrm{~b})(7)$ by picketing for more than 30 days without filing a representation petition if it had filed a meritorious $\$ 8(a)(5)$ charge-a conclusion of great importance and certainly not one which immediately appears from a reading of $\S 8(\mathrm{~b})(7)$.

16 Plauche Elec., Inc., 135 N.L.R.B. 250 (1962).

17 Town \& Country Mfg. Co., 136 N.L.R.B. 1022 (1962) ; Fibreboard Paper Prods. Corp., 138 N.L.R.B. 550 (1962), enforced, 322 F.2d 411 (D.C. Cir. 1963), aff'd, 379 U.S. 203 (1964). 1963).

18 May Dep't Stores, 136 N.L.R.B. 797, enforcement denied, 316 F.2d 797 (6th Cir.

19 Frank Sullivan \& Co., 133 N.L.R.B. 726 (1961). See also Struksness Constr. Co., 165 N.L.R.B. No. 102, 1967 CCH NLRB Dec. I 21,558 (June 26, 1967).

20 Blue Flash Express Co., 109 N.L.R.B. 591 (1954).

21 Compare 49 L.R.R.M. 3539 (1961-62), with 48 L.R.R.M. 3534 (1960-61). 
through authorization cards ${ }^{22}$ show that the process of reforming and reshaping the law inherited from Eisenhower Board appointees has not yet been completed.

It is not enough, however, to conclude that the members of the NLRB have been making policy decisions, and to tell them to stop doing so. Indeed, to give such a direction would be to command the impossible. If the Board members attempted to comply, the almost certain result would be a lower and less satisfactory level of labor law in action. This is so because the generalized provisions of the National Labor Relations Act inevitably impose upon it the responsibility for making policy decisions concerning the problems revealed in attempting to apply those general provisions to the fact patterns which change from case to case as do the vari-colored forms of a kaleidoscope.

For example, in 1935 the draftsmen of the Wagner Act might have anticipated a possible conflict between the freedom in choosing bargaining representatives guaranteed employees by section 7 of the Act ${ }^{23}$ and the preservation of collective bargaining relationships that the Act also sought to accomplish. But no one, I submit, could have contemplated all the problems involved in resolving that conflict. The NLRB has produced an elaborate set of rules, commonly referred to as the contract bar doctrine, which attempt a resolution of the conflict between these and other interests. A collective bargaining agreement meeting the tests established by these rules serves as a bar to a petition for a representation election. The specific rules constituting the doctrine relate to the length of time for which a collective bargaining agreement may serve as a bar to a representation election, ${ }^{24}$ the significance to be attached to the presence of an illegal union shop ${ }^{25}$ or "hot cargo" clause ${ }^{26}$ in a collective bargaining agreement, the effect of an unusual or unforeseen increase in the number of employees covered by the agreement, ${ }^{27}$ the timeliness of the filing of a petition, ${ }^{28}$ the insulated period for negotiation of a new contract, ${ }^{29}$ and a host of other problems.

22 Bernel Foam Prods. Co., 146 N.L.R.B. 1277 (1964). For a discussion of the subsequent developments, see Lesnick, Establishment of Bargaining Rights Without an NLRB Election, 65 MrCE. L. REv. 851 (1967); Gordon, Union Anthorization Cards and the Duty to Bargain, 67 LAB. REL. REP. 165 (1968); Comment, Employer "Good Fait/2 Doubt," 116 U. PA. L. Rev. 709 (1968).

23 NLRA § 7, 29 U.S.C. \$ 157 (1964).

24 Compare Pacific Coast Ass'n of Pulp \& Paper Mfrs., 121 N.L.R.B. 990 (1958), with General Cable Corp., 139 N.L.R.B. 1123 (1962).

25 Compare Keystone Coat, Apron \& Towel Supply Co., 121 N.L.R.B. 880 (1958), with Paragon Prods. Corp., 134 N.L.R.B. 662 (1961).

26 See Food Haulers, Inc., 136 N.L.R.B. 394 (1962).

27 See General Extrusion Co., 121 N.L.R.B. 1165 (1958).

2s Leonard Wholesale Meats, Inc., 136 N.L.R.B. 1000 (1962).

29 Id. 
These are not mere technical details, but matters of considerable importance upon which Congress might legislate. They are no more particularized than, for example, the congressional direction that an election not be held in a bargaining unit within which there has been a valid election in the last twelve months, ${ }^{30}$ or the statutory rule that recognitional picketing may not take place for more than thirty days without the filing of a representation petition. ${ }^{31}$ That the NLRB undertook to make the policy judgments requisite to the development of the contract bar doctrine should not be the occasion for congressional disapproval; nor should the fact that the Board undertakes revision in light of its experience with the doctrine be cause for criticism.

Another and more current illustration of the necessity that the Board make policy judgments can be found in the unfolding complications of the relationship between an employer's obligation to bargain with respect to certain types of subcontracting, ${ }^{32}$ the prohibition against "hot cargo" clauses added to the Act in 1959,33 and the earlier regulation of jurisdictional disputes found in section 8(b)(4)(D)..$^{34}$ Depending upon the particular fact pattern disclosed, a union demand, backed by strike action, for inclusion or enforcement of a particular contract clause may be a demand that the Board should support as included within the employer's duty to bargain, prohibit as illegal "hot cargo" activity, or subject to its procedure for resolving jurisdictional disputes. ${ }^{35}$ Congress did not provide a clear and unambiguous guide to the resolution of the problems presented, but as the cases are processed answers must be given. The giving of these answers necessarily requires the exercise of at least a policy judgment about what Congress would have done if the problem had been foreseen. Further, unless one is committed to preserving mistakes, the Board must have freedom to correct what experience reveals to have been an unwise choice. As Professor Jaffe observed, the discretion used in formulating rules cannot be used but once and then "put back in the box." 36

The occasions upon which the Board must exercise a policy judgment are not all attributable to the Board's inability to foresee problems or to the ambiguities inherent in the English language.

30 NLRA $\$ 9$ (c) (3), 29 U.S.C. \$159(c) (3) (1964).

31 NLRA \& 8(b) (7), 29 U.S.C. \& 158(b) (7) (1964).

32 Fibreboard Paper Prods. Corp. v. NLRB, 379 U.S. 203 (1964).

33 NLRA \& \&(e), 29 U.S.C. \& 158 (e) (1964).

34 NLRA \& 8(b) (4) (D), 29 U.S.C. \$ 158(b) (4) (D) (1964).

35 Compare Fibreboard Paper Prods. Corp. v. NLRB, 379 U.S. 203 (1964), with National Woodwork Mfrs. Ass'n v. NLRB, 386 U.S. 612 (1967) ; Carey v. Westinghouse Elec. Corp., 375 U.S. 261 (1964), and NLRB v. Local 1212, IBEW, 364 U.S. 573 (1961).

36 Jaffe, Basic Issues: An Analysis, 30 N.Y.U. L. Rev. 1273, 1285 (1955). 
Frankness requires recognition that from time to time the congressional advocates of management and labor interests have accepted language which obfuscated a problem rather than pursue a clear, but perhaps unfavorable, congressional policy pronouncement on the matter. For example, the legislative history of section $8(\mathrm{c}),{ }^{37}$ the "free speech" provision added in 1947, clearly reveals a problem unresolved: the extent to which the Board may look at all the circumstances to determine whether an expression contains a threat of reprisal. ${ }^{38}$ Professor Cox's personal familiarity with the legislative history of the 1959 amendments to the National Labor Relations Act has made it possible for him to assert that the parties drafting the Conference Report had no common intention regarding a very important aspect of the regulation of organizational picketing, but rather had what might be characterized as conflicting intentions. ${ }^{39}$ Given such legislation, the Board cannot avoid making policy decisions.

Since the NLRB will have to make and reassess policy judgments in the area it regulates, a political coloration will inevitably be cast upon the Board's activities. As Professor Jaffe has said, "Policymaking is politics." 40 Of course the policy-making activities should be kept at the minimum necessary for effective discharge of the Board's functions. But it should not be forgotten that the Supreme Court and the courts of appeals play an important role in checking the NLRB's ventures into unwarranted policy-making. ${ }^{11}$ Moreover, these problems would not be solved by abolishing the NLRB or turning it into a labor court. Unless vindication of the public interest in labor policy is to depend on the considerations which motivate suits by private parties, it is essential to preserve the office of the General Counsel, or something like it. The discretion that may be exercised in determining which charges should be prosecuted and which should be dropped is a discretion to shape not only the law in action but also the substantive law created in the litigation process. It is, for example, common knowledge that the antitrust policies of the United States can be sub-

37 NLRA § 8(c), 29 U.S.C. § 158(c) (1964).

38 Compare the proposed language for $\S 8(d)$ (1) found in H. R. REP. No. 3020 , 80th Cong., 1st Sess. 26 (1947) and the comment thereon in H.R. REe. No. 245, 80th Cong., 1st. Sess. 33 (1947) with the proposed language for $\$ 8(\mathrm{c})$ found in S. Rep. No. 1126, 80th Cong., 1st Sess. 16 (1947), the comment thereon in S. REP. No. 105, 80th Cong., 1st Sess. 23-24 (1947), and the conference explanation found in H. REP. No. 510 , 80th Cong., 1st Sess. 45 (1947).

30 Cox, The Landrum-Griffin Amendments to the National Labor Relations Act, 44 MinN. L. Rev. 257, 266 (1959). 1965).

$40 \mathrm{~L}$. Jaffe, Judicial Control of Administrative Action 22 (abr. student ed.

41 See, e.g., American Shipbuilding v. NLRB, 380 U.S. 300, 326 (1965) ; NLRB v. Brown, 380 U.S. 278, 290-92 (1965) ; Teamsters Local 357 v. NLRB, 365 U.S. 667 , 676 (1961) ; NLRB v. Drivers Local 639, 362 U.S. 274, 290 (1960) ; NLRB v. Insurance Agents' Int'l Union, 361 U.S. 477, 499-500 (1960); NLRB v. American Nat'l Ins. Co., 343 U.S. 395, 404 (1952). 
stantially reformulated and modified by a change in the leadership of the Antitrust Division of the Department of Justice. ${ }^{42}$

Assuming that the NLRB will continue to function as an administrative agency, I would like to direct attention to something other than the instances in which the Board may have made unnecessary or even unauthorized excursions into policy-making. I would like instead to discuss the question how the Board, utilizing the powers that it has as an administrative agency, might improve upon the techniques it uses in formulating and revising those policy decisions that it inevitably must make.

My suggestions, and my principal criticism of the NLRB's policy formulation and policy revision, relate to the Board's failure to utilize its substantive rule-making powers. I first expressed my criticism of the NLRB's neglect of its rule-making powers in an article published in the Yale Law Journal in 1961. ${ }^{43}$ A similar criticism had been made earlier by the Labor Law Section of the American Bar Association, ${ }^{44}$ and distinguished scholars and eminent practitioners have since joined the chorus. ${ }^{45}$ More significantly, Judge Henry J. Friendly has likewise suggested that the Board make use of its power to make substantive rules. ${ }^{46}$ Judge Friendly has not been the only member of the judiciary to make such a suggestion. ${ }^{47}$

There can be little doubt that the NLRB has the power to make substantive rules. Section 6 of the National Labor Relations Act specifically states:

The Board shall have authority from time to time to make, amend, and rescind in the manner prescribed by the Administrative Procedure Act, such rules and regulations as may be necessary to carry out the provisions of this Act. ${ }^{48}$

42 See T. ARNold, FaIR Fights and Fovi 120-30 (1965); Turner, Address Before the American Bar Association, 10 AnTITRUst BuLl. 685 (1965).

43 Peck, The Atrophied Rule-Making Powers of the National Labor Relationts Board, 70 Y ALE L.J. 729 (1961).

44 ABA Comar. on NLRB Practice \& Procedure, Proceedings 116, 121 (1958).

$451 \mathrm{~K}$. Davis, Administrative Law Treatise $\$ 6.13$ (1965 Pocket Part) ; Berger, Retroactive Administrative Decisions, 115 U. PA. L. REv. 371 (1967) ; Fuchs, Agency Developments of Policy Through Rule-Making, 59 Nw. U. L. REv. 781 (1965); Shapiro, The Choice of Rulemaking or Adjudication in the Development of Administrative Policy, 78 Harv. L. Rev. 921 (1965); Siegel, Problems and Procedures in the NLRB Election Process, 66 LAB. ReI. ReP. 259, 263-64 (1967).

$46 \mathrm{H}$. Friendly, The Federal Administrative Agencies $145-47$ (1962). See also his opinions in NLRB v. Penn Cork \& Closures, Inc., 376 F.2d 52 (2d Cir. 1967); NLRB v. Majestic Weaving Co., Inc., 355 F.2d 854 (2d Cir. 1966) ; NLRB v. Lorben Corp., 345 F.2d 346, 349 (2d Cir. 1965) (dissenting opinion); NLRB v. A.P.W. Prods. Co., 316 F.2d 899 (2d Cir. 1962).

47 See Operating Engineers Local 49 v. NLRB, 353 F.2d 852, 856 (D.C. Cir. 1965); McLeod v. General Elec. Co., 257 F. Supp. 690 , 708 n.14 (S.D.N.Y. 1966). See also NLRB v. E. \& B. Brewing Co., 276 F.2d 594 (6th Cir. 1960), cert. denied, 366 U.S. 908 (1961).

48 NLRA $\$ 6,29$ U.S.C. \$156 (1964). 
What there is in the legislative history of the Taft-Hartley Act indicates that the present language of the section was adopted instead of other language that might have deprived the Board of substantive rule-making powers. ${ }^{49}$ The NLRB does not deny that the statutory authorization encompasses substantive rule-making powers. And, as Professor Fuchs has pointed out, the phrase, "in the manner prescribed by the Administrative Procedure Act" would be meaningless except in relation to legally binding substantive regulations, for the rule-making procedures prescribed by the Administrative Procedure Act do not apply to any other kind of rule-making. ${ }^{50}$

The procedural requirements for substantive rule-making are neither oppressive nor burdensome. The Board must publish general notice of the proposed rule-making in the Federal Register, setting out the time and place of the proceedings, the portion of the National Labor Relations Act under which the rule was proposed, and the terms or substance of the contemplated rule. ${ }^{51}$ The Act does not require an adversary hearing, or even the reception of oral testimony or evidence. All that is necessary is that there be an opportunity for interested persons "to participate in the rule-making through submission of written data, views, or arguments with or without opportunity to present the same orally . . . "52 Rules adopted do not become effective until at least 30 days after their publication in the Federal Register, unless the Board finds good cause for establishing an earlier effective date. ${ }^{53}$ Good practice might lead the Board to utilize more formal hearing procedures, but no other restraints are imposed by statute upon the Board's use of its substantive rule-making powers. The absence of detailed prescriptions affords freedom and flexibility for the formulation of policy through procedures that can be designed for the particular occasion and problem.

Despite the ease with which the NLRB might have complied with the requirements of the Administrative Procedure Act, the Board has failed to utilize its substantive rule-making powers formally, though I

48 The minority members of the House Committee on Labor and Education saw in the proposed elimination of the Wagner Act's authorization to make "rules," as contrasted with "regulations," an attempt to eliminate the Board's statutory authority to make substantive rules. H.R. REP. No. 245, 80th Cong., 1st Sess. 75 (1947). From reinstatement of that authority one may infer an intent to preserve substantive rulemaking power. The matter is not, however, the subject of comment in the Conference Report.

50 Fuchs, Agency Development of Policy Throngh Rule-Making, 59 Nw. U. L. Rev. 781, 798 (1965).

51 Administrative Procedure Act $\$ 4(\mathrm{a}), 5$ U.S.C. 1003 (a) (1964), as amended, 5 U.S.C.A. \$ 553(b) (1967).

52 Administrative Procedure Act $\S 4(\mathrm{~b}), 5$ U.S.C. 1003(b) (1964), as amended, 5 U.S.C.A. $\$ 553$ (c) (1967).

53 Administrative Procedure Act $\$ \$ 3(\mathrm{a}), 4(\mathrm{c}), 5$ U.S.C. $1002(\mathrm{a}), 1003$ (c) (1964), as amended, 5 U.S.C.A. $\$ \$ 552$ (a), 553 (d) (1967). 
believe that upon a number of occasions it has in fact done so sub rosa, and hence improperly. One such instance was in July, 1954, when the NLRB in two press releases announced new jurisdictional standards which were first applied in decisions published three-and-one-half months later..$^{54}$ Also, in 1958 changes were made in the contract bar doctrine following an invitation, issued by press release to the interested public, for comments on a number of pending cases. ${ }^{55}$ The Board utilized those cases as vehicles for policy pronouncements and rule changes going far beyond those necessary to dispose of the cases. Indeed, the results in some of the cases were the same as they would have been under the old rules. ${ }^{56}$ Although the proof is not quite certain, I think it proper to conclude that the NLRB likewise engaged in substantive rule-making without complying with the Administrative Procedure Act in its American Potash \& Chemical Corp. decision, ${ }^{57}$ where it adopted a rule for determining appropriate bargaining units that required severance of craft groups whenever the union which sought to represent them was one which had traditionally represented that craft. ${ }^{58}$ In the same category was the NLRB's 1957 determination to outlaw all exclusive hiring hall agreements unless they contained certain provisions limiting the encouragement of union membership that ordinarily results from such agreements. ${ }^{69}$

So far as I know, Board members have not undertaken to refute charges of this sort, and I know of no court decision sustaining the charges made. ${ }^{60}$ But well known authors in the field of administrative law, although disagreeing with one another on a number of other occasions, are in agreement that at least some of the charges are justified. ${ }^{61}$ However, whether or not the Board has, on occasion, acted in violation of the provisions of the Administrative Procedure Act is not as significant as the Board's persistent refusal to utilize its

54 Peck, supra note 43 , at 735-38.

65 NLRB Press Release R-570 (July 22, 1958), 42 LAB. REL. ReP. 363 (1958).

$56 I d$.

57107 N.I.R.B. 1418 (1954).

58 Peck, supra note 43 , at 743-46.

69 Id. at 746-51.

60 Similar charges were, however, upheld by the First Circuit in Wyman Gordon Co. v. NLRB, 397 F.2d 394 (1st Cir. 1968), cert. granted, 89 S. Ct. 301 (1968)

(No. 463). See notes 75-88 infra and accompanying text.

In a supplemental memorandum filed with the Subcommittee on the Separation of Powers the NLRB has offered a defense of its failure to exercise rule-making powers. 69 LAB. REL. REP. 157. The defense is weakened by its reliance upon authorities who, while perhaps not in agreement with each of the observations and criticisms made here, have at least indicated general agreement with the proposition that the Board should use its rule-making powers. E.g., Shapiro, The Choice of Rulemaking or Adjudication in the Development of Administrative Policy, 78 HARv. L. REv. 921 (1965).

61 See 1 Davis, Administrative Law Treatise \$6.13 (1965 Pocket Part); Berger, Retroactive Administrative Decisions, 115 U. PA. L. REv. 371, 386-89 (1967). 
rule-making powers despite the urging of practitioners, academicians, and judges that it do so. ${ }^{62}$

In 1961, for example, the Board, reconstituted with President Kennedy's appointments, announced a policy change with respect to the determination of appropriate bargaining units for insurance agents. The earlier policy, adopted in 1944, had been to deny units of insurance agents less than statewide or companywide in scope. ${ }^{63}$ The case chosen as the vehicle for announcing the policy change, Quaker City Life Insurance $\mathrm{Co}_{.}{ }^{64}$ appeared to be no more than a routine three-page representation decision. The rationale for the former rule had been that unions engaged in organizing insurance agents would soon extend their membership to statewide proportions, and hence that provisional units of less than statewide scope were unnecessary if insurance agents desired collective bargaining. Asserting, without statistical or other support, that the expectation of statewide organization had not been achieved, the Board concluded that there was no longer any reason for applying a special rule for unit determinations in the insurance industry.

The conclusion may have been sound. But it would have been much more appropriate if it had been reached after the entire insurance industry had been given the opportunity to participate in the analysis of how extensive company or statewide organization had become, the reasons it had not become more extensive, the considerations relating to the desirability of the former rule, and variations of the new rule that might be adopted in its place. Indeed, one might venture to suggest that if this procedure had been followed, it would not have been necessary, as the Supreme Court later found it to be in NLRB $v$. Metropolitan Life Insurance Co., ${ }^{65}$ to require the Board to articulate the reason for the various unit determinations subsequently made in the insurance industry in order to demonstrate that it was not giving controlling effect to the extent of employee organization, a factor which may be taken into account but which may not be made conclusive. ${ }^{66}$

Similarly, in 1962 the NLRB overturned its long-standing rule that in cases involving retail chain-store operations the appropriate unit for collective bargaining should embrace employees of all stores located within an employer's administrative division or geographic area. In Sav-On Drugs, Inc. ${ }^{67}$ it announced a new policy under which determina-

62 See authorities cited supra notes $44-46$.

03 Metropolitan Life Ins. Co., 56 N.L.R.B. 1635 (1944).

64 134 N.L.R.B. 960 (1961).

65380 U.S. 438 (1965).

${ }^{80}$ See NLRA \& 9 (c) (5), 29 U.S.C. \& 159(c) (5) (1964).

67 138 N.L.R.B. 1032 (1962). 
tion of whether a proposed chain-store unit is appropriate will be made in light of all the circumstances of the case. Analysis of the desirability of the change was limited to a single paragraph of the majority opinion, and was predicated upon the conclusion that the former policy had too frequently operated to impede employees in the exercise of their rights of self-organization. Again, the conclusion may have been sound; but how much better it would have been if the empirical foundation had been subjected to scrutiny and comment by the industry to which the new rule was to be applied. Instead, although the NLRB knew that a policy change was possible when it granted review of the regional director's dismissal of the representation petition, the Board chose to make the change in a decision that in form concerned only one employer and one union. I submit that one of the consequences has been judicial skepticism that the new policy is based upon anything other than the prohibited emphasis on the extent of employee organization. $^{68}$

Another significant policy change made with respect to the appropriateness of bargaining units was the abandonment of the rule, which had prevailed since 1954, under which any group of craft employees was recognized as appropriate for severance if the union which sought to represent it was one that had traditionally represented that craft. ${ }^{69}$ It is true that the abandoned rule suffered from the anomaly of not applying to the basic steel, aluminum, lumber, and wet milling industries, and that it had been subjected to penetrating criticism by the Court of Appeals for the Fourth Circuit. ${ }^{70}$ But only blind deference to form could lead to the conclusion that the new criteria for determining the appropriateness of craft units ${ }^{71}$ constituted a rationale for the typical ad hoc or quasi-judicial decision rather than rule-making of tremendous significance. Yet the NLRB chose to give its new policy pronouncement the form of an administrative decision.

Adjudication rather than rule-making continues as the preferred means for announcing policy changes in the contract bar doctrine. ${ }^{22}$

68 E.g., NLRB v. Capital Bakers, Inc., 351 F.2d 45 (3d Cir. 1965). See also NLRB v. Davis Cafeteria, Inc., 358 F.2d 98 (5th Cir. 1966); NLRB v. Frisch's Big Boy Ill-Mar, Inc., 356 F.2d 895 (7th Cir. 1966).

69 American Potash \& Chem. Corp., 107 N.L.R.B. 1418 (1954).

70 NLRB v. Pittsburgh Plate Glass Co., 270 F.2d 167 (4th Cir. 1959), cert. denied, 361 U.S. 943 (1960).

71 The new criteria were announced in Mallinckrodt Chem. Works, 162 N.I.R.B. No. 48, 1967 CCH NLRB Dec. \20,981 (1966).

72 See General Cable Corp., 139 N.I.R.B. 1123 (1962) ; Leonard Wholesale Meats, Inc., 136 N.L.R.B. 1000 (1962); Paragon Prods. Corp., 134 N.L.R.B. 662 (1961). 
With few exceptions, ${ }^{73}$ the changes have been applied retroactively. The consequence has been either to defeat the expectations of a union which had undertaken an organizing campaign in the belief that it could obtain an election, or to defeat the expectations of an employer who thought he had bargained for and obtained a longer period of stable employment relations. These injuries to both union and employer expectations have been inflicted even though the prior rules were not unworkable and even though the wealth of experience with the doctrine accumulated by the NLRB since Wagner Act days certainly eliminated the need for an experimental approach appropriate to novel problems. ${ }^{74}$

In Excelsior Underwear, Inc. ${ }^{75}$ the NLRB announced what it called "higher standards of disclosure" 76 requiring that within seven days after approval of a consent-election agreement or direction of an election an employer must file with the regional director an election eligibility list, containing the names and addresses of all eligible voters. The list is then made available to the union and other interested parties to assist them in their campaigning. The cases that evoked the announcement came before the Board on exceptions to regional directors' recommendations that objections to conduct affecting the results of elections be overruled. Commendably, the NLRB issued an invitation to certain interested parties to file amicus briefs and participate in oral argument. That a number did so may account for the fact that the opinion contains a more detailed analysis of the problem than is found in certain of the Board's other decisions which have made important policy announcements. Also commendably, the Board determined that the new rule should be given prospective application, governing only cases in which elections were directed or consented to more than thirty days after the date of the decision. ${ }^{77}$ But as I shall suggest later, the reason for so limiting the application of the new requirement may not have been any consideration of the evils of retroactive application of law to private parties. As it was, the result in these cases, one of which had arisen more than two years earlier, gave to the unions involved only rewards comparable to those received by a patient upon whom a lengthy, thrilling, and revolutionary operation has been unsuccessfully performed. Here again, what was in fact rulemaking was accomplished as adjudication, without compliance with the Administrative Procedure Act.

73 E.g., Leonard Wholesale Meats, Inc., 136 N.L.R.B. 1000 (1962).

74 See Berger, Retroactive Administrative Decisions, 115 U. PA. L. Rev. 371, 379-84 (1967) ; Peck, supra note 43, at 738-41, 756.

75156 N.L.R.B. 1236 (1966).

$70 \mathrm{Id}$. at 1239.

77156 N.L.R.B. at 1240 n.5. 
This was the conclusion recently reached by the First Circuit in Wyman-Gordon Co. v. NLRB. ${ }^{78}$ The court found that in promulgating the Excelsior rule, the NLRB had "designed its own rulemaking procedure, adopting such part of the Congressional mandate [of the Administrative Procedure Act] as it chose and rejecting the rest." 79 The consequence was denial of enforcement to a NLRB subpoena for a names-and-addresses list, even though the court indicated that it had little or no objection to the substance of the rule or to the policy it sought to effectuate. Such a failure to effectuate policy because of the NLRB's reluctance to use formal rule-making procedures is, of course, sufficient cause for regret. But even greater cause for regret may be found by considering the benefits that might have been obtained if the problem in Excelsior had not been limited by the fiction of adjudication but instead had been open for the more complete examination available in rule-making.

Thus, as has been pointed out in an article critical of the Excelsior decision, ${ }^{80}$ several questions remained unanswered, such as whether an employer could use alternative devices like outside mailing services to meet a union's need for communication with employees ; ${ }^{81}$ whether a union could waive its right to a list in exchange for an employer's consent to an election; and what effect would be given to technical or minor errors in the list. ${ }^{32}$ Moreover, in a rule-making proceeding the Board could have passed upon the question which it said was not before it- " $[w]$ hether or not an employer's refusal to disclose employee names and addresses after an election has been directed would constitute 'interference, restraint or coercion' within the meaning of Section $8(a)$ (1) of the Act . . . ." 83 If it had attached such consequences to the refusal to disclose, the case might well have provided a means other than the Board's subpoena power for compelling production. Use of the subpoena power depends upon a conclusion that a list received for the purpose of delivery to interested parties and not made part of the record in any proceeding constitutes "evidence in such proceeding or investigation" within the meaning of section 11(2) of the Act. ${ }^{84}$

78397 F.2d 394 (1st Cir. 1968), cert. granted, 89 S. Ct. 301 (1968) (No. 463). Judge Coffin, dissenting, did not disagree with the conclusion that the NLRB had engaged in rule-making, but sought to justify the Board's action upon the ground that the Excelsior rule is a procedural rule to which the requirements of the Administrative Procedure Act do not apply. 397 F.2d at 398-99.

79 Id. at 397.

so Siegel, supra note 45 , at 259.

81 Montgomery Ward \& Co., 160 N.L.R.B. 1188 (1966).

\$2 See Valley Die Cast Corp., 160 N.L.R.B. 1881 (1966).

\$3 Excelsior Underwear, Inc., 156 N.L.R.B. 1236, 1245 (1966).

84 NLRA § 11(2), 29 U.S.C. §161(2) (1964). 
This point has been one upon which NLRB enforcement efforts have at times faltered. ${ }^{85}$

Significantly for present purposes, on the same day that the employee address list requirement was announced, the NLRB decided two cases in which the unions contended that an employer's refusal to allow a reply to an employer speech made on company time and company premises shortly before balloting prevented the holding of a free and fair election. ${ }^{56}$ They argued that the elections should therefore be set aside. The Board invited certain interested parties to file briefs amicus curiae and participate in oral argument. The problem involved was one on which the Board's policy had vacillated in a way that leaves little doubt that the vacillations were caused by changes in Board membership. ${ }^{87}$ The Board decided, however, that it would not make any change in existing policy with regard to employer speeches on company time. Its reason for doing so was that the Excelsior rule requiring production of employee lists with addresses was expected to create alternative opportunities for communication between unions and employees, and that reconsideration of the policy should be deferred until experience under the new rule had been accumulated and analyzed. ${ }^{88}$

Once again the parties whose cases were chosen for consideration of policy changes were subjected to substantial delay. One of the cases involved an election held in August, 1964, and the other an

85 NLRB v. Q-T Shoe Mfg. Co., 279 F. Supp. 1 (D. N.J. 1968) ; NLRB v. Montgomery Ward \& Co., 54 CCH Lab. Cas. II11,659 (M.D. Fla. Jan. 13, 1967) (M.D. Fla. 1966) ; NLRB v. Hanes Hosiery Div., 54 CCH Lab. Cas. T17,852 (M.D. N.C. 1966), rev'd, 384 F.2d 188 (4th Cir. 1967), cert. denied, 390 U.S. 950 (1968); see Comment, Enforcement of the Excelsior Rule in the District Conts, 116 U. PA. L. REv. 1434, 1436-41 (1968).

86 General Elec. Co., 156 N.L.R.B. 1247 (1966).

87 In 1951, an NLRB constituted primarily of members appointed by President Truman decided that an employer violated $\$ 8$ (a) (1) by making a speech to massed employees on company time and denying the union an opportunity to reply on an equal basis. Bonwit Teller, Inc., 96 N.L.R.B. 608 (1951), remanded, 197 F.2d 640 (2d Cir. 1952), cert. denied, 345 UU.S. 905 (1953). In December, 1953, a Board reconstituted by Eisenhower appointments overruled the Bonzerit Teller doctrine, and held that in the absence of either an unlawful, broad, no-solicitation rule or a privileged no-solicitation rule (broad but not unlawful because of the character of the business), an employer does not commit an unfair labor practice if he makes a pre-election speech on company time to his employees and denies the union's request for an opportunity to reply. Livingston Shirt Corp., 107 N.L.R.B. 401 (1953). The Eisenhower appointees charged that the Bonwit Teller doctrine was nothing more than the earlier captiveaudience doctrine, outlawed by $\$ 8(\mathrm{c})$ of the Taft-Hartley Act, 29 U.S.C. $\$ 158$ (c) (1964), making a reappearance in scant disguise. Id. at 407. More recently, the NLRB reconstituted with appointments made by President Kennedy announced that the Bonwit Teller doctrine still had vitality as applied to a department store having a broad, privileged, no-solicitation rule, and found that an employer had violated $\S 8(a)$ (1) by refusing to allow a union the opportunity to reply to an employer's speech made on company time. May Dep't Stores Co., 136 N.L.R.B. 797 (1962), enforcement denied, 316 F.2d 797 (6th Cir. 1963). As might be expected, the Eisenhower appointee remaining on the Board dissented. 136 N.L.R.B. at 804 (Member Rogers, dissenting).

\&s General Elec. Co., 156 N.L.R.B. 1247, 1251 (1966). 
election held in June, 1963. While it might be said that the protesting unions had no reason to complain that they did not know that their objections would not be considered meritorious until February, 1966, the same cannot be said of the employers involved, over whose employment relations there loomed the unsettling possibility that they would be held to have interfered with fair election procedures.

A similar fate awaits other parties if the Board undertakes adjudicatory reconsideration of the policy with respect to employer speeches on company time after experience with the Excelsior rule has been acquired. Why it should do so is not clear. The problem has been identified. Conceivably, legal assistants to the Board members could undertake a review of experience with the Excelsior rule so that the Board could make a more informed judgment on the matter. This would certainly be preferable to the seat-of-the-pants judgment one suspects is sometimes made under the pretence of referring to experience. But certainly a better evaluation of the rule's operation could be made if a summary, prepared by members of the General Counsel's staff with field experience, were subjected to criticism and analysis by all interested parties in rule-making proceedings.

Another example of the Board's lack of concern for the private interests affected by retroactive application of rules announced in adjudication can be found in the recent decision of a three-member panel which denied a union the certification to which the panel agreed the union was entitled under preexisting rules. ${ }^{80}$ The rule announced by the panel was that any conversation, other than minimal comments which should be dismissed as trivial, between representatives of a party and employees waiting to vote, would constitute cause for setting aside the election regardless of the contents of the remarks exchanged. The panel applied the new rule to the pending case though acknowledging that the Board had not previously "enunciated a clear standard against "which to measure" the effect of such conversations." The justification for such Draconian regulation of conversations with voters rested in part upon administrative convenience in avoiding the burdensome task of examining the substance and effect of the conversations, and in part upon the ease with which such a blanket prohibition is understood and applied by the parties. ${ }^{91}$ The former consideration, administrative convenience, certainly supplies no justification for condemning conduct which was unobjectionable by Board standards in

s9 Milchem, Inc., 170 N.L.R.B. No. 46, 1968-1 CCH NLRB Dec. (22,245 (March 14, 1966).

$90 \mathrm{Id}$.

91 Id. 
effect at the time; and the latter consideration, certainty and ease of application, obviously could have no bearing upon parties who could not have been informed of the new rule.

Analysis of the unfair labor practice determinations made by the NLRB in recent years likewise reveals a number of occasions upon which the Board might better have resorted to rule-making rather than adjudication for the announcement of new policies. In 1962 the Board instituted a policy of requiring the payment of six per cent interest on back-pay awards ordered when an employer is found to have unlawfully discharged an employee. ${ }^{92}$ There was nothing in the fact pattern of the case used to announce the policy that made consideration of the matter particularly appropriate, and, as the Board's decision stated, ${ }^{93}$ the General Counsel had made a similar request for interest awards in a number of other cases. Rule-making procedures would have avoided the appearance that the employer involved had been randomly selected as the first to be subjected to the new rule. More important, employers generally would have been able to make comments and present arguments looking toward formulation of a rule of general significance. Instead, the interests of employers in general were represented through the brief filed by the single employer involved, and the matter was decided without oral argument. Indeed, if rulemaking proceedings had been held, unions might have suggested a matter not considered in the opinion: whether the six per cent rate ordered by the Board is adequate, considering that discharged employees borrowing money will generally have to pay much higher rates of interest to small loan companies.

As mentioned above, in 1964 the Board reversed an earlier policy requiring a union to choose between filing a charge that an employer has violated its duty to bargain and proceeding with a representation election. $^{.4}$ The Board decided that a union which has lost a representation election may nevertheless establish its status as bargaining representative under the remedial order issued in an unfair labor practice proceeding upon proof that the employer unlawfully refused to bargain. The process by which the law has evolved in the four years since that pronouncement has been very competently described

82 Isis Plumbing \& Heating Co., 138 N.L.R.B. 716 (1962), enforcement denied on other groutnds, 322 F.2d 913 (9th Cir. 1963).

93138 N.L.R.B. at 717.

94 Bernel Foam Prods. Co., 146 N.I.R.B. 1277 (1964). The policy thus replaced was one that the Board had adopted in 1954 under the control of Eisenhower appointees, in Aiello Dairy Farms, 110 N.L.R.B. 1365 (1954). For the pre-Aiello policy, see Joy Silk Mills, Inc. v. NLRB, 185 F.2d 732 (D.C. Cir. 1950), cert. denied, 341 U.S. 914 (1951). 
and criticized elsewhere. ${ }^{95}$ For our purposes, it is enough to note that at a high point in the development of the doctrine, the NLRB said it would issue a bargaining order even though it did not find a refusal to bargain, if meritorious objections were filed in a pending representation case and the employer's misconduct warranted the setting aside of the election..$^{96}$ Subsequent decisions indicate a softening of the Board's position with respect to establishment of bargaining status without an election, ${ }^{97}$ and I doubt that the Board would now issue a bargaining order in the absence of a finding that the employer had refused to bargain.

Probably the policy change, or the correction of policy, made in this instance ${ }^{88}$ was of such dimension that the experimental ad hoc approach of adjudication was more appropriate than an attempt to anticipate and deal with all the problems in advance. However, the course of policy development is now strewn with the decisional remnants of the experimental approach. The experiments have been conducted; it is time to clean up the laboratory and write the report. The time has come for the Board to bring order and certainty to the area through rule-making proceedings. Judge Friendly made a similar suggestion to the Board in 1965 with respect to one aspect of the problem : whether an authorization of union representation is invalid because of statements to employees about initiation fees. ${ }^{99} \mathrm{He}$ repeated his suggestion in 1967 with respect to the entire problem of what a union authorization card should say and what misrepresentations concerning its use would invalidate it as proof of a union majority. ${ }^{100}$ But at the present time the Board's insistence on proceeding only by adjudication has deprived us of the clarification and certainty that might be obtained through rule-making.

The Court of Appeals for the District of Columbia Circuit, and Judge Friendly in a dissenting opinion, have urged rule-making with respect to what they called the recurring problem of the permissible

95 Gordon, Union Anthorization Cards and the Duty to Bargain, 67 LAB. REL. REP. 165 (1968); Lesnick, Establishment of Bargaining Rights Without an NLRB Election, 65 MICE. L. Rev. 851 (1967) ; Comment, Employer "Good Faith Donbt," 116 U. PA. L. REv. 709 (1968).

86 Irving Air Chute Co., 149 N.L.R.B. 627, 629 (1964).

97 Aaron Bros. Co., 158 N.L.R.B. 1077 (1966).

The Board does continue to make statements indicating that extensive $8(a)$ (1) violations standing alone would provide a sufficient basis for a bargaining order if they destroyed a majority established on a card check basis. E.g., Hecks Inc., 172 NLRB No. 225, 1968-1 CCH NLRB Dec. $\int 20,202$ (Sept. 24, 1968). However, the cases in which the statements have been made recently are all cases in which there was a demand for bargaining which the employer unlawfully refused.

98 See note 94 sipra and accompanying text.

99 Amalgamated Clothing Workers v. NLRB, 345 F.2d 264, 269 (2d Cir. 1965) (concurring opinion).

100 Bryant Chucking Grinder Co. v. NLRB, 389 F.2d 565, 568-72 (2d Cir. 1967) (concurring opinion). 
limits of employer questioning of employees concerning union affiliation and activities, ${ }^{101}$ but the Board's response has been no more than a clarifying adjudicatory decision. ${ }^{102}$ Reviewing courts have likewise found no response to suggestions that the Board make rules with respect to such matters as whether an employer's liability for back pay should be tolled for the period of time between a trial examiner's dismissal of a charge and a Board decision to the contrary. ${ }^{103}$ Judge Friendly was ready to make failure to utilize rule-making powers the basis for reversal of the Board when it abandoned its rule that negotiation of a contract with a minority union did not violate the Act if the contract was conditioned upon the union establishing a majority among the

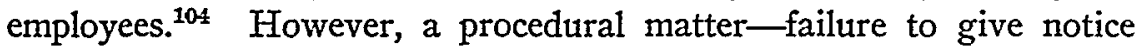
that the legality of the negotiation was an issue-provided a surer ground for reversal. ${ }^{105}$ In 1966 the Court of Appeals for the Third Circuit also expressed the view that the Board could do a better job of developing policy considerations and outlining minimal standards for the problems related to fines assessed by unions against members, ${ }^{106}$ but the Board has manifested no interest in doing so. Despite the administrative fiasco of ad hoc outlawing of exclusive hiring halls, ${ }^{107}$ the Board has never responded to the Sixth Circuit's suggestion that the Board might have more success if it utilized its substantive rulemaking powers. ${ }^{108}$

Other examples might be discussed, ${ }^{100}$ but I think it may be taken as established that the NLRB persists in its refusal to utilize its rulemaking power, and adamantly adheres to adjudication as the sole vehicle for announcement and revision of policy. The proposition that rule-making proceedings are not suited to the functions of the NLRB has been proven false by the Board's use on a number of occasions of what in substance must be viewed as rule-making, but rule-making conducted without all the benefits and protections that would be obtained through compliance with the Administrative Procedure Act

101 Operating Engineers Local 49 v. NLRB, 353 F.2d 582 (D.C. Cir. 1965); NLRB v. Lorben Corp., 345 F.2d 346, 350 (2d Cir. 1965) (Friendly, J., dissenting).

102 Struksnes Constr. Co., 165 N.I.R.B. 1385 (1967).

103 See the suggestion for such a rule in NLRB v. A.P.W. Prods., Inc., 316 F.2d 899, 905 (2d Cir. 1963).

104 NLRB v. Majestic Weaving Co., 355 F.2d 854, 859-61 (2d Cir. 1966).

105 Id. at $861-63$.

${ }^{108}$ Leeds \& Northrup Co. v. NLRB, 357 F.2d 527 (3d Cir. 1966).

107 See Peck, supra note 43, at 746-51.

108 NLRB v. E. \& B. Brewing Co., 276 F.2d 594 (6th Cir. 1960), cert. dentied, 366 U.S. 908 (1961).

100 E.g., McLeod v. General Elec. Co., 257 F. Supp. 690, 708 (S.D.N.Y.), rev'd, 366 F.2d 847 (2d Cir. 1966), set aside and remanded, 385 U.S. 533 (1967). 
and hence subject to judicial disapproval as "agency action . . . found to be . . . without observance of procedure required by law." 110

Receipt of amicus briefs and oral arguments in some cases in which policy changes were made was certainly preferable to deciding the matter solely upon the basis of argument by the General Counsel and whoever happened to be the attorneys for the private parties involved. But in many cases the argument takes place on the basis of a record compiled without knowledge that a policy change was in the offing. Undoubtedly more information could be obtained from the affected public in a rule-making proceeding. The peculiar facts of a particular case and the issues thereby suggested in light of precedent must be a poor substitute for the more comprehensive rules that are or should be under consideration. The experience of all affected parties might enable them to point out defects in the comprehensive rules that are unforeseen or of no interest to the parties involved in the adjudicatory proceeding. Indeed, in this respect the adjudicatory aspects of the proceeding may be a distraction from the more important policy formulation taking place.

The product of adjudication is also inferior to what could be produced by rule-making insofar as it serves as a guide to the agency staff and the regulated public. Unless the adjudicatory decision is distorted with dictum on situations not involved in the case being decided, both agency and regulated public must resort to reading a line of cases and formulating from them a statement of the principles or policies followed by the NLRB with respect to a particular matter. This is not only time-consuming and expensive because of its dependence upon specialized talents cultivated primarily by lawyers, but also productive of error and conflict because of inevitable misreadings. It may be true that few of the specialists in labor law have been misled by the NLRB's failure to use its rule-making powers, but to the extent possible the Board should try to be of service to non-specialists, whether laymen or lawyers.

I have suggested that adjudication may have an adverse effect upon the determination of policy and the development of rules. I would also like to suggest that use of adjudication for policy formulation may also have adverse effects upon the adjudicatory product. The parties to the proceedings selected for announcement of changes in policy may find themselves swept up into a maelstrom of argument ranging far beyond their immediate concerns. In such a situation attention may be directed away from the peculiar facts of what might otherwise be a relatively unimportant case.

110 Administrative Procedure Act $\S 10,5$ U.S.C. $\S 1009$ (e) (1964), as amended 5 U.S.C. $\$ 706(D)$ (1967); see Peck, supra note 43, at 754-55. 
For example, in one of the cases involved in the 1958 revision of the contract bar doctrine, ${ }^{111}$ the Board devoted seven pages of its decision to a hypothetical discussion of how it would decide cases involving other parties and other facts. Only four pages of the decision were devoted to the case at hand, and those pages included the Board's rejection of the petitioning union's reasonable suggestion that the new rules be made prospective in operation. The Board rejected the suggestion because it thought that issuance of a prospective decision would create "an administrative monstrosity." 112 Perhaps in a proper adjudicative proceeding the merits of the union's suggestion would have been recognized.

More recently, the Ninth Circuit refused enforcement of the Board's order in the case in which it announced that payment of interest would be required on back pay due under reinstatement orders. ${ }^{113}$ The reason for denying enforcement was the rather unusual one that the evidence supporting the Board's fact findings did not meet the test established by the Supreme Court in Universal Camera Corp. ${ }^{114}$ One wonders whether such errors in fact finding would have been made if attention had been focused on adjudicatory facts rather than the more exciting policy issue.

One of the most serious adverse effects of using the adjudicatory process for policy formulation is, of course, the retroactive effect upon parties who legitimately relied upon the former rules. For example, it is probably sound to rule that execution of a collective bargaining agreement with a minority union is prohibited assistance under section $8(a)(2)^{115}$ even though the effectiveness of the agreement is deferred until such time as the union obtains a majority. But as Judge Friendly has said, the judicial hackles rise when such a ruling is applied to require refund of union dues and initiation fees by employers who relied upon clear Board precedent that such an agreement was permitted under the Act. ${ }^{116}$

Courts make retroactive policy changes in the course of their adjudications, but courts have no substantive rule-making powers. The comparison provides no comfort for the NLRB, and indeed is embarrassing when consideration is given to the growing use of prospective overruling by courts to avoid the evils of retroactivity. ${ }^{117}$

111 Deluxe Metal Furniture Co., 121 N.L.R.B. 995 (1958).

112 Id. at 1006-07.

113 NLRB v. Isis Plumbing \& Heating Co., 322 F.2d 913 (9th Cir. 1963).

114 Universal Camera Corp. v. NLRB, 340 U.S. 474 (1951).

115 NLRA \& \& (a) (2), 29 Ü.S.C. \$158(a) (2) (1964).

116 NLRB v. Majestic Weaving Co., 355 F.2d 854, 860 (2d Cir. 1966).

117 Sec, e.g., City of Fairbanks v. Schaible, 375 P.2d 201 (Alas. 1962) ; Molitor v. Kaneland Community Unit Dist., 18 I11.2d 11, 163 N.E.2d 89 (1959); Parker v. Port Huron Hosp., 361 Mich. 1, 105 N.W.2d 1 (1960); Spanel v. Mounds View 
This is not to say that the NLRB has never made a prospective ruling. It did so in establishing the Excelsior requirement that employers furnish lists of the names and home addresses of employees for delivery to interested parties.118 A few of the decisions involving changes in the contract bar doctrine were also given prospective application. ${ }^{119}$ But the uncomfortable impression gained from reading the cases is that the reason for making those rulings prospective was that retroactive rulings would have interfered with the NLRB's processing of its caseload. In short, to serve its own interests, rather than out of consideration for the parties involved, the NLRB is willing to create what it once called "an administrative monstrosity." 120 But for private parties, even though there is no pressing need and alternatives are readily available, the Board has employed what Jeremy Bentham called "dog law": the dog learns from the blow that follows that his master does not approve of what the dog has done. ${ }^{121}$

Of course there are other matters of self-interest behind the Board's adherence to adjudication for announcement of policy changes. Though judicial realists have effectively demolished the proposition that courts do not make law, there still remains some aura of "finding the law" through the adjudicatory process. It is not the policy preferences of the adjudicator that are placed in effect; instead the true law is found, or the error of earlier adjudicators corrected. The adjudicator need not justify the policies because they are not his; they have existed for all time, or at least since the particular statute involved was enacted.

Even if the adjudicator is willing to admit performing a policymaking function, he may prefer the maneuverability of the adjudicatory process. Having set out the adjudicatory decision, the administrator may observe what happens to it without exposing the entire scheme that will be put into effect if the decision finds acceptance. If the decision fails to obtain acceptance, a much less embarrassing retreat may be made. ${ }^{122}$ If a reviewing court enforces the adjudicatory order

School Dist., 264 Minn. 279, 118 N.W.2d 795 (1962) ; Graham v. Rolandson, 435 P.2d 263, 274 (Mont. 1967); Holytz v. City of Milwaukee, 17 Wis. $2 d$ 26, 115 N.W.2d 618 (1962); Levy, Realist Jurisprudente and Prospective Overruling, 109 U. PA. L. Rev. 1 (1960); Note, Prospective Overruling and Retroactive Application in the Federal Courts, 71 Yale L.J. 907 (1962).

118 Excelsior Underwear, Inc., 156 N.L.R.B. 1236 (1966).

119 Goodyear Tire \& Rubber Co., 138 N.L.R.B. 453 (1962); Leonard Wholesale Meats, Inc., 136 N.L.R.B. 1000 (1962); Ideal Elec. \& Mfg. Co., 134 N.L.R.B. 1275 (1961).

120 Deluxe Metal Furniture Co., 121 N.L.R.B. 995, 1006-07 (1958).

1215 The Works of Jeremy Bentham 235 (1st ed. J. Bowring 1808), quoted in C. Gregory, Labor aNd the Law 52 (1st ed. 1946).

122 See Siegel, supra note 80, at 264. 
on some other ground, the administrator may continue to pursue his policy, perhaps with refinements gained from the experience. ${ }^{123}$ To make policy determinations by substantive rule would, from the administrator's viewpoint, have the unfortunate effect of binding the agency until such time as the rule were changed by regular proceedings. ${ }^{124}$

It is with regret that I make these suggestions. My regret is not that from time to time the NLRB makes policy decisions or revises policy. It is with the manner in which the Board does so. As I have already indicated, I think it impossible that the NLRB escape a policy-making role. Statutes cannot be drawn with a clairvoyant precision that eliminates all subsequent policy-making. As Justice Frankfurter said in a different but related context, "There are no talismanic words that can avoid the process of judgment." ${ }^{125}$ Deciding when an administrative agency should proceed to develop policy on an ad hoc basis through adjudication and when it should resort to formal rule-making involves judgment upon a multitude of factors. The choice of an appropriate procedure, as the Supreme Court has said, must be the product of the exercise of an informed discretion. ${ }^{120}$ But the Board's blanket refusal to utilize its conceded rule-making powers compels the conclusion that the NLRB has been derelict in failing to take advantage of the flexibility possible in the administrative process.

Of particular relevance is the fact that rule-making proceedings would clearly identify the policy-making activities of the NLRB, thus facilitating supervision by the courts and by Congress. Rule-making proceedings, while by no means a substitute for representative government, would provide interested parties with an opportunity to be heard and to present their views on policies of importance to them. As it is, the regulated public all too frequently learns of a policy change after its adoption. Then the public must bear the burden of persuading: administrators that the change they have already made is erroneous or should be altered in one respect or another. It would be to ignore too much of what we know of human nature to say that this additional burden is not a significant one. Finally, even if we must expect the administrative development to reflect the political factors which determine appointment to the agency, the inevitable changes will be more acceptable if they are announced prospectively, as is legislation, which, of course, is likewise affected by political factors. 